\title{
Global Proteome Changes in Liver Tissue 6 Weeks after FOLFOX Treatment of Colorectal Cancer Liver Metastases
}

\author{
Jozef Urdzik ${ }^{1, *}$, Anna Vildhede ${ }^{2,+}$, Jacek R. Wiśniewski ${ }^{3}$, Frans Duraj ${ }^{1}$, Ulf Haglund ${ }^{1}$, \\ Per Artursson ${ }^{2}$ and Agneta Norén ${ }^{1}$ \\ 1 Department of Surgical Sciences, Uppsala University, SE-75185 Uppsala, Sweden; \\ frans.duraj@surgsci.uu.se (F.D.); ulf.haglund@akademiska.se (U.H.); agneta.noren@akademiska.se (A.N.) \\ 2 Department of Pharmacy, Uppsala University, SE-75237 Uppsala, Sweden; \\ Anna.Vildhede@pfizer.com (A.V.); per.artursson@farmaci.uu.se (P.A.) \\ 3 Department of Proteomics and Signal Transduction, Max-Planck-Institute of Biochemistry, \\ Martinsried 82152, Germany; jwisniew@biochem.mpg.de \\ * Correspondence: jozef.urdzik@surgsci.uu.se; Tel.: +46-18-611-0000 \\ + Current affliction: Pharmacokinetics Dynamics and Metabolism, Pfizer Global Research and Development, \\ Pfizer Inc., Groton, CT 06340, USA.
}

Academic Editor: Dariusz Rakus

Received: 17 August 2016; Accepted: 7 October 2016; Published: 14 October 2016

\begin{abstract}
Oxaliplatin-based chemotherapy for colorectal cancer liver metastasis is associated with sinusoidal injury of liver parenchyma. The effects of oxaliplatin-induced liver injury on the protein level remain unknown. (2) Protein expression in liver tissue was analyzed-from eight patients treated with FOLFOX (combination of fluorouracil, leucovorin, and oxaliplatin) and seven controls-by label-free liquid chromatography mass spectrometry. Recursive feature elimination-support vector machine and Welch $t$-test were used to identify classifying and relevantly changed proteins, respectively. Resulting proteins were analyzed for associations with gene ontology categories and pathways. (3) A total of 5891 proteins were detected. A set of 184 (3.1\%) proteins classified the groups with a $20 \%$ error rate, but relevant change was observed only in $55(0.9 \%)$ proteins. The classifying proteins were associated with changes in DNA replication $(p<0.05)$ through upregulation of the minichromosome maintenance complex and with the innate immune response $(p<0.05)$. The importance of DNA replication changes was supported by the results of Welch $t$-test $(p<0.05)$. (4) Six weeks after FOLFOX treatment, less than $1 \%$ of identified proteins showed changes in expression associated with DNA replication, cell cycle entry, and innate immune response. We hypothesize that the changes remain after recovery from FOLFOX treatment injury.
\end{abstract}

Keywords: oxaliplatin-based chemotherapy; protein expression; label-free liquid chromatography mass spectrometry; DNA replication; minichromosome maintenance complex; innate immune response; recovery of liver injury

\section{Introduction}

Preoperative chemotherapy for colorectal liver metastases (CRLM) plays an important role in the multimodal treatment strategy. Liver resection is the only curative treatment and additional preoperative chemotherapy can convert initially non-resectable CRLM to resectable disease [1] or prolong disease-free survival in primary resectable patients [2]. Oxaliplatin-based treatment regimens, such as a fluorouracil, leucovorin, and oxaliplatin combination (FOLFOX), is commonly used as first-line chemotherapy for CRLM. Oxaliplatin-based treatment is, however, associated with sinusoidal injury (SI) in the liver parenchyma, which is reported in 5\% [3] to 50\% [4,5] of treated patients. 
Severe SI is clinically associated with increased perioperative bleeding and increased postoperative morbidity [6,7], usually without clinical manifestation of hepatotoxicity during or after therapy [8]. Several clinical studies show that the effect of oxaliplatin-based treatment is reversible and that the liver recovers after chemotherapy cessation $[9,10]$. Some patients develop SI after only a short period of treatment, while others do not develop SI despite prolonged treatment. This evokes the hypothesis of an individual susceptibility to oxaliplatin-induced injury [11]. The association of SI development with polymorphisms in the nucleotide excision repair genes ERCC2 [12], copper transporter ATP7B [13], and glutathione S-transferase M1 [14] supports the hypothesis.

The exact molecular pathway behind the oxaliplatin-induced liver parenchyma injury remains unclear. Microarray studies attempting to investigate the whole panorama of changes associated with oxaliplatin-based treatment and SI development in humans show an involvement of angiogenesis, cellular adhesion, oxidative stress, and extracellular matrix components [11,15] together with activation of acute phase response, coagulation system, hepatic fibrosis, and hypoxic factors [15]. The role of the mentioned processes is supported by the findings of several studies focusing on particular pathways: angiogenesis [16], oxidative stress [16-20], extracellular matrix remodeling [21,22], and prothrombotic changes $[11,23]$. However, these changes can also be explained by the presence of CRLM itself [24]. Acute hepatocyte injury caused by the exposure of cultivated hepatocytes to cisplatin (platinum compound similar to oxaliplatin) showed a large proportion (29\%) of changes in the proteome [25].

The present study attempts to evaluate the effects of FOLFOX treatment on normal human liver tissue. Changes in protein expression were quantified using label-free liquid chromatography-tandem mass spectrometry (LC-MS/MS) and were investigated for associations with biological processes and pathways.

\section{Results}

\subsection{Clinical Data}

During the study period, 47 patients resected for CRLM donated liver tissue samples to the biobank. Seven patients had no chemotherapy prior to liver surgery and represented a control group. Thirteen patients received preoperative FOLFOX treatment without any biologic agents, and eight of them were randomly selected for the treated group. Patients in the treated group received a median of 5 cycles (interquartile range (IQR) 5-6) of FOLFOX with a median interval of 6 (IQR 5-8) weeks between the last treatment and surgery. Patients were on average 59 years old (IQR 58-69), with a majority of males, $73 \%(11 / 15)$, and had an average body mass index (BMI) of $26 \mathrm{~kg} / \mathrm{m}^{2}$ (IQR 24-30). There was no difference in clinical characteristics between the groups; for details see Supplementary Material Table S1.

\subsection{Proteome Description}

LC-MS/MS analysis allowed identification of 58,757 unique peptides matching to 6689 unique proteins in the liver samples, and 5891 unique proteins that were identified in $>50 \%$ of the samples were subjected to statistical analysis. Unsupervised hierarchical clustering according to average Euclidean distance (Figure 1A) showed that 10 of $15(67 \%)$ technical pairs were grouped together at the first order of clustering. The treated patients were, however, mixed with controls in around $50 \%$ of the final two clusters, as shown in Figure 1A. Principal component analysis (PCA) showed a similar pattern of compact dataset with no obvious discriminating component between the treated and nontreated group. A scatter plot of component 1 (explaining 20.1\% of data distribution) versus component $2(10.8 \%)$ revealed an obvious shift between the technical replicates in both groups, mainly in the direction of component 1 (Figure 1B). After subtraction of component 1, no remaining intraindividual shift was observed. The intraindividual variability was less than the interindividual variability based on the PCA scatter plot. FOLFOX treatment did not induce changes in protein patterns that were detectable by unsupervised hierarchical clustering or PCA. 


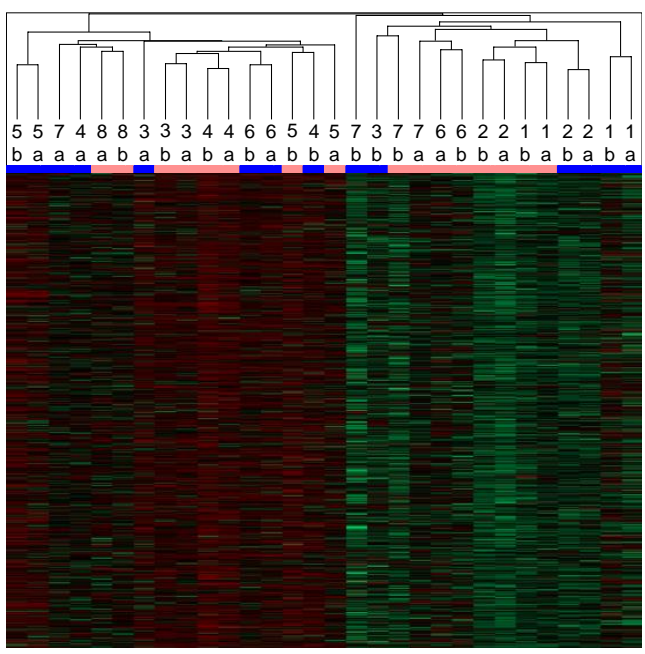

(A)

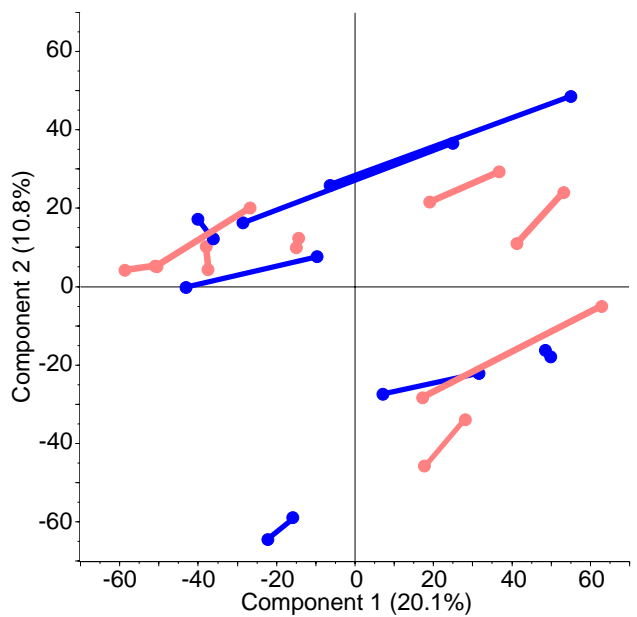

(B)

Figure 1. Proteome data description: (A) Unsupervised hierarchical clustering using average Euclidean distance, pink color for FOLFOX-treated patients, blue color for controls. Patient number and technical replicates marked with $\mathrm{a}$ or $\mathrm{b}$ are provided. Treated and control patients were mixed together in final two clusters. (B) Principal component analysis (PCA), FOLFOX group in pink and controls in blue, pairs of technical repeats are joined with interconnecting lines. No obvious separation was detected by PCA.

\subsection{Classification of the FOLFOX-Treated and Control Group on the Basis of Protein Expression}

Classifying proteins between the treated group and controls were identified using recursive feature elimination-support vector machine (RFE-SVM) feature optimization algorithm with an attempt to reach high power of enrichment analysis. The smallest number of the proteins providing the minimal classification error rate of $20 \%$ was 184 (Figure 2). These 184 proteins are listed in rank order in Supplementary Material Table S2.

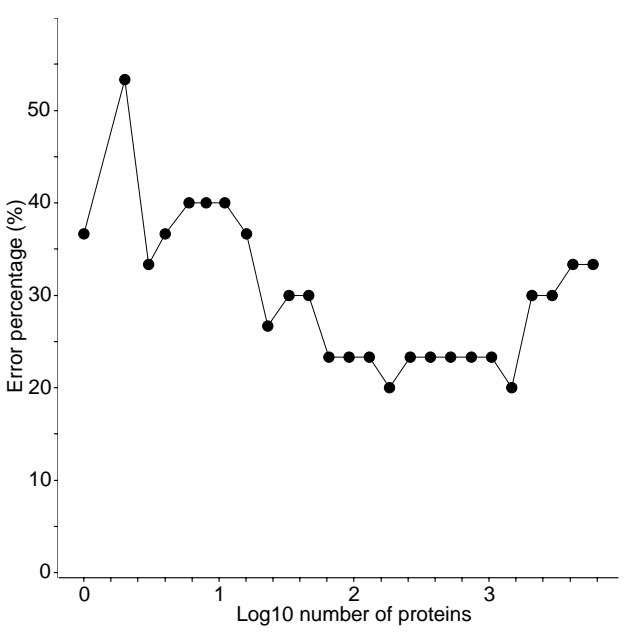

(A)

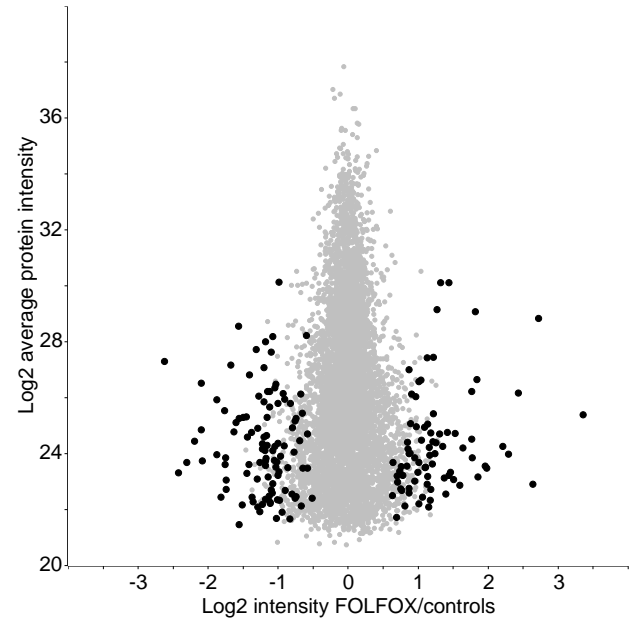

(B)

Figure 2. Classification feature optimization method utilizing recursive feature elimination-support vector machine. All identified proteins were ranked according to their classification ability, used in model learning, and cross-validated by leave-one-out method. Logarithm of number of the proteins used in model was plotted against classification error rate (A) and average protein change was plotted against average protein intensity (B), with the 184 best classifying proteins giving a classification error rate of $20 \%$ marked in black and the rest of proteins in grey. 


\subsection{Proteome Differences between FOLFOX-Treated and Control Group}

Welch $t$-test identified $46(0.8 \%$ of all identified) proteins that showed a significant difference in abundance between the treated and nontreated group ( $p$-value $<0.05$, false discovery ration $($ FDR $)<0.05)$. Most of the identified proteins were found in the lower half of the LC-MS/MS dynamic range (i.e., expressed in low abundance, Figure 3A). After manual optimization of $\mathrm{s}_{0}$ parameter to $0.05,55(0.9 \%)$ proteins were recognized as statistically significant and biologically relevantly changed (Figure 3B). Twenty-one proteins were upregulated in the treated group vs controls, with a median fold change of +2.4 (IQR 2.0-3.2) while 34 were downregulated with a median fold change of -2.4 (IQR -3.3 to -2.0 ). For the complete list of changed proteins, see Table 1.

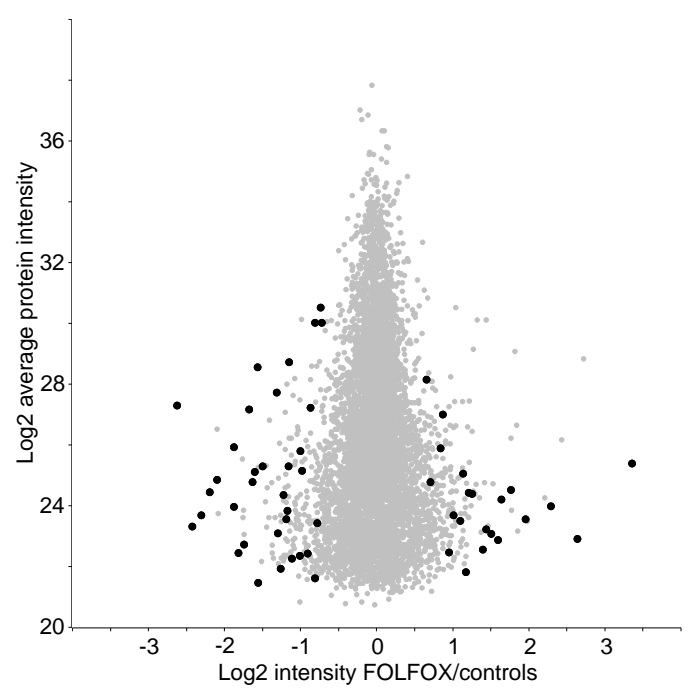

(A)

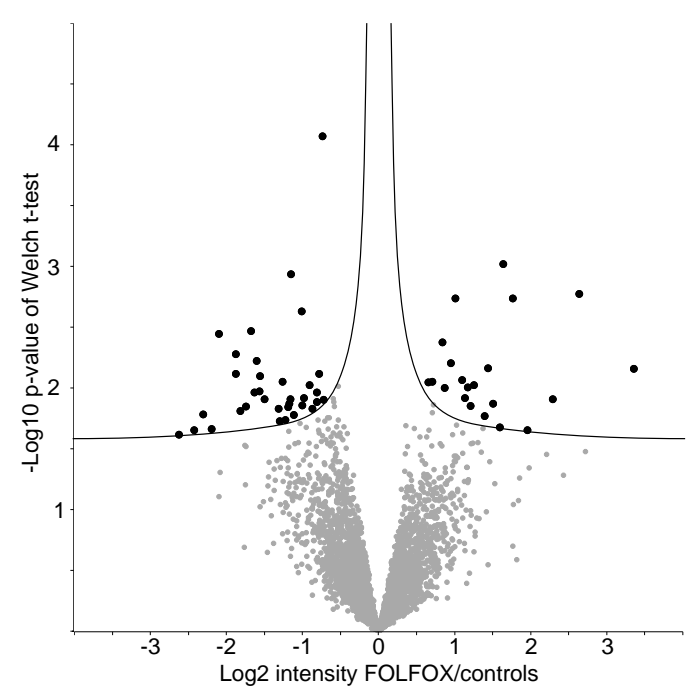

(B)

Figure 3. Welch $t$-test relevantly changed proteins, $p$-value $<0.05$, false discovery ratio $<0.05, \mathrm{~s}_{0}=0.05$. (A) Logarithm of FOLFOX-treated patients and controls intensities ratio is plotted against average signal intensity of protein and (B) against Welch $t$-test $p$-value, with relevantly changed proteins in black and the rest of proteins in grey. Proteins under $\mathrm{s}_{0}$ curves but over log-transformed $p$-value threshold were statistically significant, but their biologic effect was judged as marginal.

Table 1. List of relevantly changed proteins according to Welch $t$-test, at false discovery ratio $<0.05$, $\mathrm{s}_{0}=0.05$. Numbers of identified peptides and unique peptides are also provided.

\begin{tabular}{|c|c|c|c|c|c|c|}
\hline $\begin{array}{c}\text { Gene } \\
\text { Names }\end{array}$ & Protein Names & $\begin{array}{c}\text { Welch } t \text {-Test } \\
p \text {-Value }\end{array}$ & $\begin{array}{c}\text { Fold } \\
\text { Change }\end{array}$ & $\begin{array}{l}\text { Coefficient } \\
\text { of Variation }\end{array}$ & Peptides & $\begin{array}{l}\text { Unique } \\
\text { Peptides }\end{array}$ \\
\hline MAP1B & $\begin{array}{l}\text { Microtubule-associated protein 1B;MAP1 light } \\
\text { chain LC1 }\end{array}$ & 0.007 & 10.21 & 1.43 & 24 & 23 \\
\hline HLA-DQA1 & $\begin{array}{c}\text { Major histocompatibility complex, class II, } \\
\text { DQ alpha } 1\end{array}$ & 0.002 & 6.23 & 1.12 & 4 & 2 \\
\hline C19orf52 & Uncharacterized protein C19orf52 & 0.012 & 4.90 & 1.92 & 3 & 3 \\
\hline IGHD & Ig delta chain $C$ region & 0.022 & 3.88 & 1.82 & 7 & 7 \\
\hline MCM2 & DNA replication licensing factor MCM2 & 0.002 & 3.40 & 0.80 & 12 & 12 \\
\hline MLIP & Muscular LMNA-interacting protein & 0.001 & 3.11 & 0.74 & 4 & 4 \\
\hline STMN2 & Stathmin-2 & 0.021 & 3.02 & 0.93 & 1 & 1 \\
\hline Q7Z7K6 & Centromere protein $\mathrm{V}$ & 0.013 & 2.84 & 1.37 & 8 & 3 \\
\hline MCM4 & DNA replication licensing factor MCM4 & 0.007 & 2.71 & 0.82 & 7 & 7 \\
\hline EMG1 & $\begin{array}{l}\text { Ribosomal RNA small subunit } \\
\text { methyltransferase NEP1 }\end{array}$ & 0.017 & 2.63 & 1.17 & 4 & 4 \\
\hline NUDT12 & Peroxisomal NADH pyrophosphatase NUDT12 & 0.009 & 2.38 & 0.73 & 8 & 8 \\
\hline $\begin{array}{l}\text { DHFR; } \\
\text { DHFRL1 }\end{array}$ & $\begin{array}{c}\text { Dihydrofolate reductase;Dihydrofolate reductase, } \\
\text { mitochondrial }\end{array}$ & 0.014 & 2.31 & 0.62 & 2 & 2 \\
\hline OSBPL6 & Oxysterol-binding protein-related protein 6 & 0.010 & 2.25 & 0.84 & 3 & 3 \\
\hline MCM7 & DNA replication licensing factor MCM7 & 0.012 & 2.20 & 0.71 & 11 & 11 \\
\hline ANGPTL3 & Angiopoietin-related protein 3 & 0.009 & 2.14 & 0.62 & 5 & 5 \\
\hline
\end{tabular}


Table 1. Cont.

\begin{tabular}{|c|c|c|c|c|c|c|}
\hline $\begin{array}{c}\text { Gene } \\
\text { Names }\end{array}$ & Protein Names & $\begin{array}{c}\text { Welch } t \text {-Test } \\
p \text {-Value }\end{array}$ & $\begin{array}{c}\text { Fold } \\
\text { Change }\end{array}$ & $\begin{array}{l}\text { Coefficient } \\
\text { of Variation }\end{array}$ & Peptides & $\begin{array}{c}\text { Unique } \\
\text { Peptides }\end{array}$ \\
\hline TMEM2 & Transmembrane protein 2 & 0.002 & 2.02 & 0.51 & 4 & 4 \\
\hline DDX20 & Probable ATP-dependent RNA helicase DDX20 & 0.006 & 1.94 & 0.54 & 4 & 4 \\
\hline ISG15 & Ubiquitin-like protein ISG15 & 0.010 & 1.82 & 0.67 & 5 & 5 \\
\hline CCDC25 & Coiled-coil domain-containing protein 25 & 0.004 & 1.79 & 0.59 & 9 & 9 \\
\hline NBEAL1 & Neurobeachin-like protein 1 & 0.009 & 1.63 & 0.52 & 10 & 10 \\
\hline BCO2 & Beta,beta-carotene 9,10 -oxygenase & 0.009 & 1.57 & 0.43 & 22 & 22 \\
\hline HAL & Histidine ammonia-lyase & 0.013 & -1.65 & 0.46 & 25 & 25 \\
\hline ASAH1 & $\begin{array}{l}\text { Acid ceramidase;Acid ceramidase subunit } \\
\text { alpha;Acid ceramidase subunit beta }\end{array}$ & 0.000 & -1.66 & 0.38 & 15 & 15 \\
\hline CYP2S1 & Cytochrome P450 2S1 & 0.008 & -1.72 & 0.45 & 2 & 2 \\
\hline GPX1 & Glutathione peroxidase 1 & 0.011 & -1.76 & 0.55 & 13 & 13 \\
\hline CLEC16A & Protein CLEC16A & 0.013 & -1.76 & 0.60 & 1 & 1 \\
\hline ACTR1B & Beta-centractin & 0.015 & -1.83 & 0.51 & 9 & 4 \\
\hline CHMP1A & Charged multivesicular body protein $1 \mathrm{a}$ & 0.009 & -1.87 & 0.56 & 1 & 1 \\
\hline CTBS & Di- $N$-acetylchitobiase & 0.012 & -1.98 & 0.71 & 5 & 5 \\
\hline $\begin{array}{l}\text { FOLH1; } \\
\text { FOLH1B }\end{array}$ & $\begin{array}{c}\text { Glutamate carboxypeptidase 2;Putative } \\
N \text {-acetylated-alpha-linked acidic dipeptidase }\end{array}$ & 0.014 & -2.01 & 0.74 & 8 & 8 \\
\hline KHNYN & Protein KHNYN & 0.002 & -2.02 & 0.59 & 2 & 2 \\
\hline FRG1 & Protein FRG1 & 0.017 & -2.17 & 0.92 & 3 & 3 \\
\hline SRP72 & Signal recognition particle $72 \mathrm{kDa}$ protein & 0.001 & -2.22 & 0.68 & 19 & 19 \\
\hline PLSCR3 & Phospholipid scramblase 3 & 0.012 & -2.23 & 0.56 & 2 & 2 \\
\hline ERF & ETS domain-containing transcription factor ERF & 0.013 & -2.25 & 0.66 & 3 & 3 \\
\hline FNBP1 & Formin-binding protein 1 & 0.014 & -2.28 & 0.75 & 5 & 5 \\
\hline SEPP1 & Selenoprotein $\mathrm{P}$ & 0.018 & -2.34 & 0.69 & 2 & 2 \\
\hline RHPN2 & Rhophilin-2 & 0.009 & -2.40 & 0.89 & 4 & 4 \\
\hline ELOVL1 & Elongation of very long chain fatty acids protein 1 & 0.019 & -2.46 & 1.61 & 2 & 2 \\
\hline MRPS7 & $28 \mathrm{~S}$ ribosomal protein $\mathrm{S} 7$, mitochondrial & 0.015 & -2.48 & 0.76 & 9 & 9 \\
\hline RIN1 & Ras and Rab interactor 1 & 0.012 & -2.82 & 0.55 & 2 & 2 \\
\hline ITIH5 & Inter-alpha-trypsin inhibitor heavy chain H5 & 0.008 & -2.95 & 1.23 & 3 & 3 \\
\hline $\begin{array}{l}\text { CAMK2G; } \\
\text { CAMK2A; } \\
\text { CAMK2B }\end{array}$ & $\begin{array}{l}\text { Calcium/calmodulin-dependent protein kinase } \\
\text { type II subunit } \\
\text { gamma;Calcium/calmodulin-dependent protein } \\
\text { kinase type II subunit alpha }\end{array}$ & 0.011 & -2.96 & 0.88 & 8 & 2 \\
\hline NT5DC2 & 5-nucleotidase domain-containing protein 2 & 0.006 & -3.04 & 0.92 & 4 & 4 \\
\hline FAN1 & Fanconi-associated nuclease 1 & 0.011 & -3.09 & 1.02 & 3 & 3 \\
\hline OXNAD1 & $\begin{array}{l}\text { Oxidoreductase NAD-binding domain-containing } \\
\text { protein } 1\end{array}$ & 0.003 & -3.20 & 1.04 & 5 & 5 \\
\hline ALOX5AP & Arachidonate 5-lipoxygenase-activating protein & 0.014 & -3.34 & 1.25 & 2 & 2 \\
\hline MACF1 & $\begin{array}{l}\text { Microtubule-actin cross-linking factor } 1, \\
\text { isoforms } 1 / 2 / 3 / 5\end{array}$ & 0.016 & -3.52 & 1.57 & 83 & 0 \\
\hline СРA3 & Mast cell carboxypeptidase A & 0.008 & -3.67 & 1.72 & 4 & 4 \\
\hline KRT80 & Keratin, type II cytoskeletal 80 & 0.005 & -3.67 & 0.64 & 5 & 4 \\
\hline MYBPC2 & Myosin-binding protein $C$, fast-type & 0.004 & -4.29 & 0.96 & 4 & 3 \\
\hline ERAP2 & Endoplasmic reticulum aminopeptidase 2 & 0.022 & -4.59 & 0.99 & 20 & 20 \\
\hline YOD1 & Ubiquitin thioesterase OTU1 & 0.017 & -4.95 & 1.56 & 3 & 3 \\
\hline TLCD1 & TLC domain-containing protein 1 & 0.022 & -5.37 & 2.22 & 2 & 2 \\
\hline UBE3B & Ubiquitin-protein ligase E3B & 0.024 & -6.17 & 0.96 & 7 & 7 \\
\hline
\end{tabular}

\subsection{Protein Ontology and Pathway Analysis}

The proteins included in the RFE-SVM classifying model showed significant association with the DNA replication pathway (FDR corr. $p$-value 0.021). A higher abundance of the minichromosome maintenance (MCM) complex proteins-MCM2, MCM4, and MCM7-was observed in the treated group (FDR corr. $p$-value $<0.001$ ), as seen in Table 2. This complex is involved in the process of DNA unwinding during replication. Moreover, the innate immune response process was also associated with proteins in the RFE-SVM model (FDR corrected $p$-value $=0.029)$. Enrichment analysis of the proteins with relevantly different abundance in the treated group compared to controls verified the role of the abovementioned DNA replication pathway and process of DNA unwinding. Interaction enrichment analysis in STRING showed significantly more observed protein-protein interactions than expected by chance in the significantly different and RFE-SVM protein groups $(p<0.001)$. The most confident interactions were observed between the MCM complex proteins, but proteins associated with the innate immune response were interacting with the whole network of identified proteins (Figure 4). 
Table 2. Gene ontology and pathways associated with significantly changed or classifying proteins.

\begin{tabular}{|c|c|c|c|c|c|c|c|}
\hline \multirow{2}{*}{ Category } & \multirow[b]{2}{*}{ Term } & \multicolumn{3}{|c|}{$\begin{array}{l}\text { Welch } t \text {-Test Significant Proteins } \\
\qquad(n=55)\end{array}$} & \multicolumn{3}{|c|}{ Classifying Model Selected Proteins $(n=184)$} \\
\hline & & $p$-Value & $\begin{array}{l}p \text {-Value } \\
\text { FDR }\end{array}$ & $\begin{array}{l}\text { Intersection } \\
\text { Genes }\end{array}$ & $p$-Value & $\begin{array}{l}p \text {-Value } \\
\text { FDR }\end{array}$ & Intersection Genes \\
\hline \multirow[b]{2}{*}{$\begin{array}{l}\text { Biological } \\
\text { Process }\end{array}$} & $\begin{array}{c}\text { DNA } \\
\text { unwinding } \\
\text { involved in } \\
\text { replication }\end{array}$ & $<0.001$ & 0.013 & $\begin{array}{l}\text { MCM2; } \\
\text { MCM4; } \\
\text { MCM7 }\end{array}$ & $<0.001$ & 0.007 & $\begin{array}{l}\text { MCM2; MCM4; MCM6; } \\
\text { MCM7 }\end{array}$ \\
\hline & $\begin{array}{l}\text { innate } \\
\text { immune } \\
\text { response }\end{array}$ & & & & $<0.001$ & 0.029 & $\begin{array}{l}\text { BCL2; C4B; CAMK2B; CD4; } \\
\text { ENSG00000228284; HCK; } \\
\text { HLA-DR4; IGKV4-1; } \\
\text { IGLV7-43; ISG15; LGALS3; } \\
\text { MAPKAPK3; MBL2; MX1; } \\
\text { NCAM1; RPS6KA1; VNN1 }\end{array}$ \\
\hline $\begin{array}{l}\text { Cellular } \\
\text { Component }\end{array}$ & $\begin{array}{l}\text { MCM } \\
\text { complex }\end{array}$ & & & & $<0.001$ & $<0.001$ & $\begin{array}{l}\text { MCM4; MCM5; MCM6; } \\
\text { MCM7 }\end{array}$ \\
\hline Pathway & $\begin{array}{l}\text { DNA } \\
\text { replication }\end{array}$ & $<0.001$ & 0.013 & $\begin{array}{l}\text { MCM2; } \\
\text { MCM4; } \\
\text { MCM7 }\end{array}$ & $<0.001$ & 0.021 & $\begin{array}{l}\text { MCM2; MCM4; MCM5; } \\
\text { MCM6; MCM7 }\end{array}$ \\
\hline
\end{tabular}

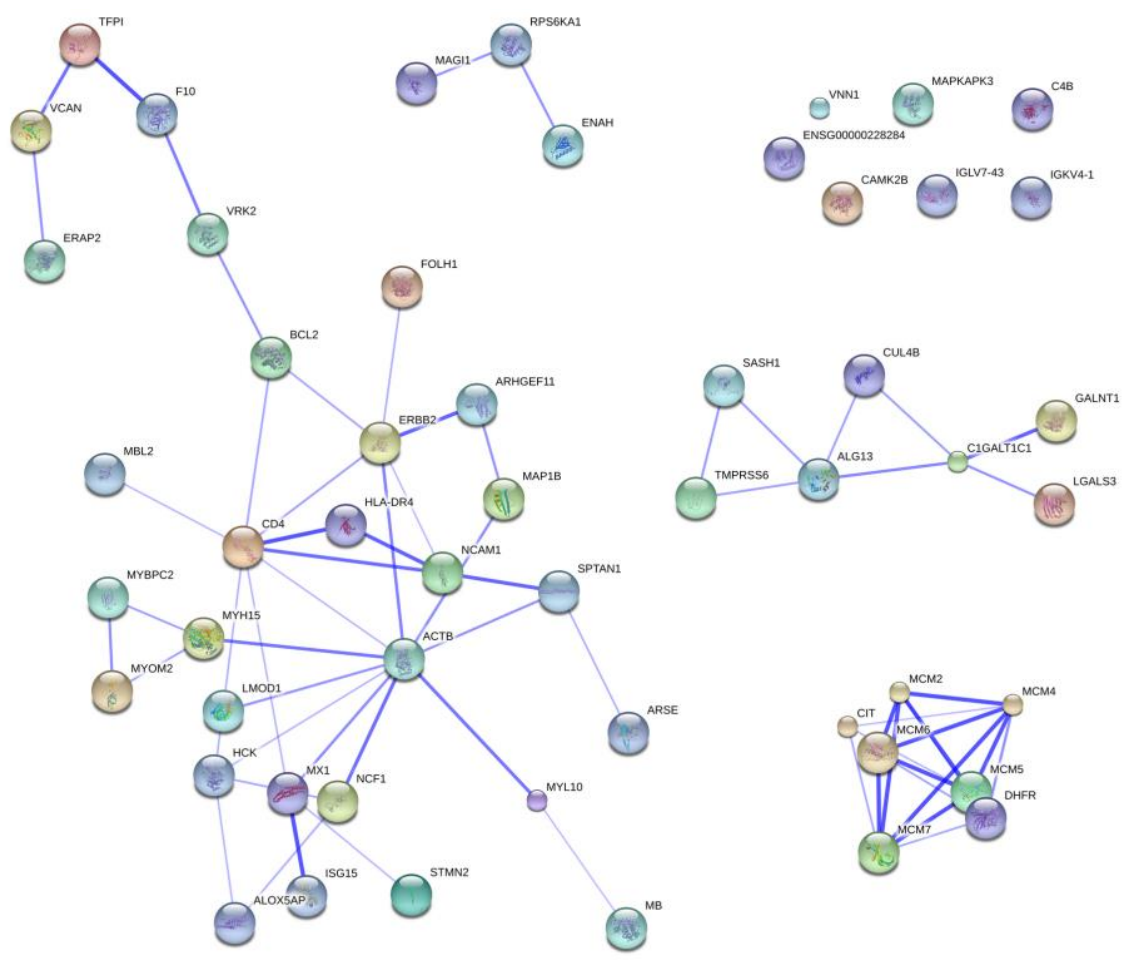

Figure 4. Protein interaction map. Proteins intersecting with ontology or pathway categories (Table 1) are visualized together with proteins interacting with them from classifying model identified list (Supplementary Material Table S2). Thicker lines represent stronger associations.

\section{Discussion}

This study documented liver parenchyma proteome changes, 6 weeks after FOLFOX treatment, in about $1 \%$ of identified proteins. The proteome changes were associated with upregulation of the MCM complex, which—by the process of DNA unwinding-increases DNA replication and indicates cell cycle entry. Observed changes after FOLFOX treatment remain in non-tumorous liver tissue at the time of liver surgery. To our knowledge, this is the first study to analyze effects of FOLFOX treatment on non-tumorous human liver tissue at the global protein expression level. 
The shotgun proteomics methods used in the study has several strengths and is a useful complement to other global methods in biomedicine [26]. Its global character helps to minimize confirmation bias, similar to microarray techniques. When the complex tissue is analyzed, isolation and preparation of the more stable proteins for LC-MS/MS is advantageous, if compared to limited quality and quantity of isolated RNA for microarray studies. Protein quantification provides insight to the results of gene expression analysis and also reflects posttranscriptional regulation [27], while the amount of mRNA copies does not necessarily reflect the amount of translated protein [28].

Acute hepatocyte injury in cultivated rat hepatocytes after exposure to cisplatin (a platinum-based cytostatic similar to oxaliplatin) for $24 \mathrm{~h}$ revealed significant changes in $29 \%$ (95/325) of the quantified proteins [25]. In contrast, our data reflect proteome changes 6 weeks after oxaliplatin exposure and only showed changes in about 1\% (55/5891) of quantified proteins. Hepatocytes occupy almost $80 \%$ and all the other cell populations only $6.5 \%$ of total liver volume [29], which implies that observed proteome changes were mostly reflecting changes in hepatocytes. This leads to the hypothesis that recovery of liver tissue from acute FOLFOX injury during the 6 weeks between the last treatment and surgery (time of tissue sampling) minimized the effects on proteome. Similarly, indirect clinical signs of FOLFOX injury, like splenomegaly, reverse after cessation of chemotherapy [9]. In addition, discrepancy between proportions of proteome changes can be partially explained by the variability of the whole liver tissue proteome, which can conceal changes observable in separated cell populations [25].

The major mechanism of oxaliplatin is the formation of platinum-DNA adducts leading to retarded replication and transcription, and ultimately to apoptotic cell death [30]. Mitosis and apoptosis rates in liver is normally low $(<0.1 \%)$, which makes their estimation difficult [31], but significant changes in DNA replication [32] and MCM complex [33] were observed in the treated group. Increased expression of MCM2 is a sensitive marker of cell cycle entry [34]. The changes identified using stringent statistics (Welch $t$-test) may represent a compensatory effect/recovery of non-tumorous liver tissue from FOLFOX effects [10]. The association of FOLFOX treatment with changes in the expression of proteins involved in the innate immune response is more complex, since identified proteins interacted within the whole network of proteins (Figure 4). The involved proteins, (Table 2), point to processes of oxidative-stress response and ischemia-induced cell death (CAMK2B, VNN1), apoptosis (BCL2, LGALS3), complement activation (C4B, MBL2), and extracellular matrix remodeling (VCAN, NCAM1). These findings are in agreement with previous findings regarding the importance of oxidative stress [16-19], and extracellular matrix remodeling [21] in the molecular pathway of oxaliplatin. Despite the possibility that changes in nonspecific stress and immune response may lead to subordinated processes, none were verified in enrichment analysis. This suggests that initial signaling is attenuated and does not proceed to further changes in liver proteome, or alternatively, that these changes were not recognized due to interindividual variability and small study groups. Finally, the most probable explanation to the observed cell cycle entry is the hypothesis that only the proteome changes remaining after recovery from the effects of FOLFOX treatment were observed, which agrees with the small proportion of proteome changes noted. Cell cycle entry may also reflect the onset of nodular regenerative hyperplasia, one of the SI histopathological patterns [5].

Identified proteome changes were mostly in the lower part of the LC-MS/MS dynamic range (Figures 2B and 3A), which may be influenced by missing data imputation. Comparison with studies primarily focused on SI-associated transcriptome changes [11,15] is problematic, since no pathological evaluation of SI was performed in the present study. Pathways recognized to be important for SI development in a microarray study by Rubbia-Brandt et al. did not overlap with our proteome analysis. This is probably due to the use of both patients with and without FOLFOX treatment in the control group (without SI) in the microarray analysis [15]. Nevertheless, the classifying proteins showed small, but significant (Fisher exact test $p$-value 0.047 ) overlap with genes associated with SI in a microarray study by Agostini et al. [11]. The overlap of three proteins, namely COL3A1, VCAN, and TMPRSS6, was significant, despite that only one third (26/81) of the original list of genes was identified in the 
present study. These three proteins are important in extracellular matrix remodeling, but as mentioned above, no association to such an enrichment category was observed.

\section{Materials and Methods}

\subsection{Patients and Liver Tissue Samples}

Normal liver tissue samples were obtained from patients undergoing a major liver resection for CRLM at Uppsala University Hospital (Uppsala, Sweden) between 2009 and 2012 (Uppsala Regional Ethical approval No. 2009/028). All donors gave their informed consent. The non-tumorous liver tissue samples were cut directly in the operation room after the liver specimen was out of the patient, and immediately stored at $-80^{\circ} \mathrm{C}$ until further proteomic analysis was conducted.

\subsection{Preparation of Tissue Lysates}

Thawed pieces (about $50 \mathrm{mg}$ ) of human liver tissue were homogenized on ice in $0.1 \mathrm{M}$ Tris- $\mathrm{HCl}$, pH 8.0, containing 0.1 M DTT using T10 basic Ultra Turrax blender (IKA, Staufen, Germany) for 10-20 s. The ratio of buffer to tissue was 12:1. To lyse the homogenate, SDS was added to a final concentration of $2 \%$ and the mixtures were immediately placed in a boiling water bath $\left(100{ }^{\circ} \mathrm{C}\right)$ for $5 \mathrm{~min}$. After chilling to room temperature, the lysates were clarified by centrifugation at $16,000 \times g$ for $10 \mathrm{~min}$. Protein concentration in the lysates was determined by the tryptophan fluorescence assay [35]. Each lysate was processed and analyzed in duplicate.

\subsection{Sample Processing}

Aliquots of the liver lysates containing $100 \mu \mathrm{g}$ total protein were separated from the detergent and DTT using the filter-aided sample preparation (FASP) procedure [36] using $30 \mathrm{k}$ ultrafiltration units (MRCF0R030, Millipore, Merck KGaA, Darmstadt, Germany). Thiol-moieties of proteins were alkylated with $0.05 \mathrm{M}$ iodoacetamide. Cleavage of proteins was carried out by a consecutive two-step digestion with endoproteinase LysC (WAKO Chemicals, Neuss, Germany) and trypsin (Invitrogen, now Thermo Fisher Scientific, Waltham, MA USA) as described previously [37]. The weight ratio of the total protein to the proteinases was 100:1. The yields of the protein to peptide conversion were $>75 \%$.

\subsection{Removal of Substances Affecting Liquid Chromatography-Tandem Mass Spectrometry (LC-MS/MS)}

Five microgram aliquots of the LysC and tryptic peptides were brought to $\mathrm{pH} 11$ with $1 \times$ Britton \& Robinson Universal Buffer (BRUB) containing $0.1 \mathrm{M} \mathrm{CH}_{3} \mathrm{COOH}, 0.1 \mathrm{M} \mathrm{H}_{3} \mathrm{PO}_{4}$, and $0.1 \mathrm{M}$ $\mathrm{H}_{3} \mathrm{BO}_{3}$ adjusted with $\mathrm{NaOH}$ to $\mathrm{pH}$ 11. The samples were subsequently loaded into pipette-tip-SAX microcolumns as described previously [38]. The columns were washed with $200 \mu \mathrm{L}$ of $0.2 \times$ BRUB $\mathrm{pH}$ 11. The flow-through fractions were discarded. Peptides were eluted with $200 \mu \mathrm{L}$ of $0.2 \times$ BRUB pH 2 (adjusted with $\mathrm{NaOH}$ ) and collected in $\mathrm{C}_{18}$-StageTips [39]. Finally, the peptides were released from the Stage Tips with $40 \mu \mathrm{L} 60 \% \mathrm{CH}_{3} \mathrm{CN}$ in water. The organic solvent was evaporated and the volumes of the peptide solutions were reduced to about $5 \mu \mathrm{L}$ in a speed-vac. This step was essential for reproducible liquid chromatography and efficient $\mathrm{MS}^{2}$-peptide identification (LC-MS/MS).

\subsection{LC-MS/MS and Raw Data Analysis}

Peptides were separated on a reverse-phase column $(20 \mathrm{~cm} \times 75 \mu \mathrm{m}$ inner diameter $)$ packed in-house with $1.8 \mu \mathrm{m}$ C18 particles (Maisch, Ammerbuch-Entringen, Germany) using a $4 \mathrm{~h}$ ACN gradient in $0.1 \%$ formic acid at a flow rate of $250 \mathrm{~nL} / \mathrm{min}$. The column was operated at a constant temperature of $35^{\circ} \mathrm{C}$. The LC was coupled to a Q Exactive mass spectrometer (Thermo Fisher Scientific, Waltham, MA, USA) via the nanoelectrospray source (Thermo Fisher Scientific). The Q Exactive was operated in the data-dependent mode with survey scans acquired at a resolution of 50,000 at $\mathrm{m} / \mathrm{z} 400$ (transient time $256 \mathrm{~ms}$ ). Up to the top 10 most abundant isotope patterns with charge 
$\geq 2$ from the survey scan were selected with an isolation window of 1.6 Th and fragmented by higher energy collisional dissociation with normalized collision energies of 25 . The maximum ion injection times for the survey scan and the MS/MS scans were 20 and $60 \mathrm{~ms}$, respectively, and the ion target value for both scan modes were set to $10^{6}$. The spectra were analyzed using the Max Quant software (version 1.2.2.8, Max-Planck-Institute of Biochemistry, Martinsried, Germany; http://www.coxdocs.org) with the "matching between runs" option. The proteins were identified by searching MS and MS/MS data of peptides against UniProtKB human database (version April 2013; http:/ / www.uniprot.org). Carboamidomethylation of cysteines was set as fixed modification. The minimum peptide length was specified to be seven amino acids. The initial maximal mass tolerance in MS mode was set to $7 \mathrm{ppm}$, whereas fragment mass tolerance was set to $20 \mathrm{ppm}$ for fragmentation data. The maximum false peptide discovery rate was specified as 0.01 . The FDR threshold was derived by analyzing the decoy database. Max Quant label-free quantification was used.

For proteins that were detected in more than $50 \%$ of samples, zero intensities were filled with intensities from the lower part of normal distribution (imputation width $=0.3$, shift $=1.8$ ) using Perseus 1.4.1.3 software (Max-Planck-Institute of Biochemistry, Martinsried, Germany; http://www. coxdocs.org).

\subsection{Statistical Analysis}

Clinical data were described using proportions, median, and interquartile range (IQR). Differences between groups were judged by Fisher exact test or Mann-Whitney test as appropriate in IBM $^{\circledR}$ SPSS ${ }^{\circledR}$ Statistics 22.0 (Armonk, NY, USA). Proteome data analysis was performed using Perseus software. To assess intra- and interindividual proteome variability, unsupervised hierarchical clustering (on z-scored data) according to average Euclidean distance and principal component analysis (PCA) were performed for all the technical replicates. Classification feature optimization was used to identify classifying proteins between the study groups. All the proteins were ranked according their classification ability using recursive feature elimination-support vector machine (RFE-SVM) (standard parameters $c=100$, reduction factor 1.414) and cross-validated according to the leave-one-out method by RFE-SVM (linear Kernel, $\mathrm{c}=10$, size reduction factor $=1.414$ ). The best classifying proteins were identified as the smallest set of highly ranked proteins achieving minimal classification error rate. Differently expressed proteins were identified using Welch $t$-test corrected for false discovery ratio (FDR) $<5 \%$ counted by permutation method with 5000 runs and manually tuned exchangeability factor $\mathrm{s}_{0}$. The method prevented influence of possible technical bias by strictly omitting technical replicates from permutations counting [40]. Optimal $\mathrm{s}_{0}$ (percentile of the standard deviation values of all the proteins) ensures that both significance and fold change is taken into account through adjustment of the significance threshold. In brief, the significance level is lowered for proteins displaying a high fold change and raised for proteins with a small fold change. The lists of classifying and relevantly changed proteins were analyzed for physical and functional associations using STRING 9.1 (String Consortium; $\mathrm{http}$ // / string-db.org). Connections were expressed as a sum of functional evidence and action scores. Overlaps with gene ontology categories and pathways were expressed using FDR-adjusted $p$-value. Adjusted or unadjusted (when appropriate) $p$-values of less than 0.05 were recognized as significant.

\section{Conclusions}

Only a small proportion ( $1 \%)$ of the proteome of non-tumorous human liver parenchyma was changed in patients 6 weeks after FOLFOX treatment. Changes were associated with cell cycle entry through MCM complex activity and with the innate immune response. This indicates that these are the only remaining proteome changes that persist in liver parenchyma after recovery from the FOLFOX treatment.

Supplementary Materials: The following are available online at www.mdpi.com/2227-7382/4/4/30/s1, Table S1: Clinical data, Table S2: Classifying proteins according Recursive Feature Elimination-Support Vector Machine 
model resulting in list of 184 proteins with classifying error rate 20\%. RAW files and the MaxQuant search results were deposited in PRIDE repository database [41] with the dataset identifier: PXD001889.

Acknowledgments: We thank Matthias Mann for continuous support and Katharina Zettl for technical assistance. This work was supported by the Max-Planck Society for the Advancement of Science.

Author Contributions: J.U., A.V., F.D., U.H., P.A., and A.N. conceived and designed the experiments; A.V. and J.R.W. designed and performed proteomic analysis. J.U. and A.V. analyzed the data; J.U. wrote the paper.

Conflicts of Interest: The authors declare no conflict of interest. The founding sponsors had no role in the design of the study; in the collection, analyses, or interpretation of data; in the writing of the manuscript, and in the decision to publish the results.

\section{Abbreviations}

The following abbreviations are used in this manuscript:

$\begin{array}{ll}\text { CRLM } & \text { Colo-Rectal cancer Liver Metastases } \\ \text { FOLFOX } & \text { Fluorouracil Leucovorin Oxaliplatin treatment } \\ \text { SI } & \text { Sinusoidal Injury } \\ \text { PCA } & \text { Principal Component Analysis } \\ \text { RFE-SVM } & \text { Recursive Feature Elimination-Support Vector Machine } \\ \text { FDR } & \text { False Discovery Ratio } \\ \text { MCM } & \text { minichromosome maintenance complex } \\ \text { LC-MS/MS } & \text { Liquid chromatography-tandem mass spectrometry }\end{array}$

\section{References}

1. Adam, R.; Delvart, V.; Pascal, G.; Valeanu, A.; Castaing, D.; Azoulay, D.; Giacchetti, S.; Paule, B.; Kunstlinger, F.; Ghemard, O.; et al. Rescue surgery for unresectable colorectal liver metastases downstaged by chemotherapy: A model to predict long-term survival. Ann. Surg. 2004, 240, 644-657; discussion 657-658. [CrossRef] [PubMed]

2. Nordlinger, B.; Sorbye, H.; Glimelius, B.; Poston, G.J.; Schlag, P.M.; Rougier, P.; Bechstein, W.O.; Primrose, J.N.; Walpole, E.T.; Finch-Jones, M.; et al. Perioperative chemotherapy with folfox4 and surgery versus surgery alone for resectable liver metastases from colorectal cancer (eortc intergroup trial 40983): A randomised controlled trial. Lancet 2008, 371, 1007-1016. [CrossRef]

3. Vauthey, J.N.; Pawlik, T.M.; Ribero, D.; Wu, T.T.; Zorzi, D.; Hoff, P.M.; Xiong, H.Q.; Eng, C.; Lauwers, G.Y.; Mino-Kenudson, M.; et al. Chemotherapy regimen predicts steatohepatitis and an increase in 90-day mortality after surgery for hepatic colorectal metastases. J. Clin. Oncol. 2006, 24, 2065-2072. [CrossRef] [PubMed]

4. Rubbia-Brandt, L.; Audard, V.; Sartoretti, P.; Roth, A.D.; Brezault, C.; Le Charpentier, M.; Dousset, B.; Morel, P.; Soubrane, O.; Chaussade, S.; et al. Severe hepatic sinusoidal obstruction associated with oxaliplatin-based chemotherapy in patients with metastatic colorectal cancer. Ann. Oncol. 2004, 15, 460-466. [CrossRef] [PubMed]

5. Rubbia-Brandt, L.; Lauwers, G.Y.; Wang, H.; Majno, P.E.; Tanabe, K.; Zhu, A.X.; Brezault, C.; Soubrane, O.; Abdalla, E.K.; Vauthey, J.N.; et al. Sinusoidal obstruction syndrome and nodular regenerative hyperplasia are frequent oxaliplatin-associated liver lesions and partially prevented by bevacizumab in patients with hepatic colorectal metastasis. Histopathology 2010, 56, 430-439. [CrossRef] [PubMed]

6. Lehmann, K.; Rickenbacher, A.; Weber, A.; Pestalozzi, B.C.; Clavien, P.A. Chemotherapy before liver resection of colorectal metastases: Friend or foe? Ann. Surg. 2012, 255, 237-247. [CrossRef] [PubMed]

7. Aloia, T.; Sebagh, M.; Plasse, M.; Karam, V.; Levi, F.; Giacchetti, S.; Azoulay, D.; Bismuth, H.; Castaing, D.; Adam, R. Liver histology and surgical outcomes after preoperative chemotherapy with fluorouracil plus oxaliplatin in colorectal cancer liver metastases. J. Clin. Oncol. 2006, 24, 4983-4990. [CrossRef] [PubMed]

8. Vietor, N.O.; George, B.J. Oxaliplatin-induced hepatocellular injury and ototoxicity: A review of the literature and report of unusual side effects of a commonly used chemotherapeutic agent. J. Oncol. Pharm. Pract. 2012, 18, 355-359. [CrossRef] [PubMed]

9. Overman, M.J.; Maru, D.M.; Charnsangavej, C.; Loyer, E.M.; Wang, H.; Pathak, P.; Eng, C.; Hoff, P.M.; Vauthey, J.N.; Wolff, R.A.; et al. Oxaliplatin-mediated increase in spleen size as a biomarker for the development of hepatic sinusoidal injury. J. Clin. Oncol. 2010, 28, 2549-2555. [CrossRef] [PubMed] 
10. Siddik, Z.H. Cisplatin: Mode of cytotoxic action and molecular basis of resistance. Oncogene 2003, 22, 7265-7279. [CrossRef] [PubMed]

11. Agostini, J.; Benoist, S.; Seman, M.; Julie, C.; Imbeaud, S.; Letourneur, F.; Cagnard, N.; Rougier, P.; Brouquet, A.; Zucman-Rossi, J.; et al. Identification of molecular pathways involved in oxaliplatin-associated sinusoidal dilatation. J. Hepatol. 2012, 56, 869-876. [CrossRef] [PubMed]

12. Pilgrim, C.H.; Brettingham-Moore, K.; Pham, A.; Murray, W.; Link, E.; Smith, M.; Usatoff, V.; Evans, P.M.; Banting, S.; Thomson, B.N.; et al. Mrna gene expression correlates with histologically diagnosed chemotherapy-induced hepatic injury. HРB 2011, 13, 811-816. [CrossRef] [PubMed]

13. Robinson, S.M.; Mann, J.; Manas, D.M.; Mann, D.A.; White, S.A. An experimental study to identify the potential role of pharmacogenomics in determining the occurrence of oxaliplatin-induced liver injury. $H P B$ 2013, 15, 581-587. [CrossRef] [PubMed]

14. Vreuls, C.P.; Olde Damink, S.W.; Koek, G.H.; Winstanley, A.; Wisse, E.; Cloots, R.H.; van den Broek, M.A.; Dejong, C.H.; Bosman, F.T.; Driessen, A. Glutathione s-transferase m1-null genotype as risk factor for sos in oxaliplatin-treated patients with metastatic colorectal cancer. Br. J. Cancer 2013, 108, 676-680. [CrossRef] [PubMed]

15. Rubbia-Brandt, L.; Tauzin, S.; Brezault, C.; Delucinge-Vivier, C.; Descombes, P.; Dousset, B.; Majno, P.E.; Mentha, G.; Terris, B. Gene expression profiling provides insights into pathways of oxaliplatin-related sinusoidal obstruction syndrome in humans. Mol. Cancer Ther. 2011, 10, 687-696. [CrossRef] [PubMed]

16. DeLeve, L.D.; Shulman, H.M.; McDonald, G.B. Toxic injury to hepatic sinusoids: Sinusoidal obstruction syndrome (veno-occlusive disease). Semin. Liver Dis. 2002, 22, 27-42. [CrossRef] [PubMed]

17. Laurent, A.; Nicco, C.; Chereau, C.; Goulvestre, C.; Alexandre, J.; Alves, A.; Levy, E.; Goldwasser, F.; Panis, Y.; Soubrane, O.; et al. Controlling tumor growth by modulating endogenous production of reactive oxygen species. Cancer Res. 2005, 65, 948-956. [PubMed]

18. Alexandre, J.; Nicco, C.; Chereau, C.; Laurent, A.; Weill, B.; Goldwasser, F.; Batteux, F. Improvement of the therapeutic index of anticancer drugs by the superoxide dismutase mimic mangafodipir. J. Natl. Cancer Inst. 2006, 98, 236-244. [CrossRef] [PubMed]

19. Deleve, L.D.; Wang, X.; Tsai, J.; Kanel, G.; Strasberg, S.; Tokes, Z.A. Sinusoidal obstruction syndrome (veno-occlusive disease) in the rat is prevented by matrix metalloproteinase inhibition. Gastroenterology 2003, 125, 882-890. [CrossRef]

20. Mikalauskas, S.; Mikalauskiene, L.; Bruns, H.; Nickkholgh, A.; Hoffmann, K.; Longerich, T.; Strupas, K.; Buchler, M.W.; Schemmer, P. Dietary glycine protects from chemotherapy-induced hepatotoxicity. Amino. Acids 2011, 40, 1139-1150. [CrossRef] [PubMed]

21. Zeng, H.H.; Lu, J.F.; Wang, K. The effect of cisplatin and transplatin on the conformation and association of f-actin. Cell. Biol. Int. 1995, 19, 491-497. [PubMed]

22. Robinson, S.M.; Mann, J.; Vasilaki, A.; Mathers, J.; Burt, A.D.; Oakley, F.; White, S.A.; Mann, D.A. Pathogenesis of folfox induced sinusoidal obstruction syndrome in a murine chemotherapy model. J. Hepatol. 2013, 59, 318-326. [CrossRef] [PubMed]

23. Fernandez, M.; Mejias, M.; Garcia-Pras, E.; Mendez, R.; Garcia-Pagan, J.C.; Bosch, J. Reversal of portal hypertension and hyperdynamic splanchnic circulation by combined vascular endothelial growth factor and platelet-derived growth factor blockade in rats. Hepatology 2007, 46, 1208-1217. [CrossRef] [PubMed]

24. Robinson, S.M.; Mann, D.A.; Manas, D.M.; Oakley, F.; Mann, J.; White, S.A. The potential contribution of tumour-related factors to the development of folfox-induced sinusoidal obstruction syndrome. Br. J. Cancer 2013, 109, 2396-2403. [CrossRef] [PubMed]

25. Cho, Y.E.; Singh, T.S.; Lee, H.C.; Moon, P.G.; Lee, J.E.; Lee, M.H.; Choi, E.C.; Chen, Y.J.; Kim, S.H.; Baek, M.C. In-depth identification of pathways related to cisplatin-induced hepatotoxicity through an integrative method based on an informatics-assisted label-free protein quantitation and microarray gene expression approach. Mol. Cell. Proteomics 2012, 11. [CrossRef] [PubMed]

26. Leung, K.S.; Fong, B.M. Lc-ms/ms in the routine clinical laboratory: Has its time come? Anal. Bioanal. Chem. 2014, 406, 2289-2301. [CrossRef] [PubMed]

27. Lundberg, E.; Fagerberg, L.; Klevebring, D.; Matic, I.; Geiger, T.; Cox, J.; Algenas, C.; Lundeberg, J.; Mann, M.; Uhlen, M. Defining the transcriptome and proteome in three functionally different human cell lines. Mol. Syst. Biol. 2010, 6, 450. [CrossRef] [PubMed] 
28. Nagaraj, N.; Wisniewski, J.R.; Geiger, T.; Cox, J.; Kircher, M.; Kelso, J.; Paabo, S.; Mann, M. Deep proteome and transcriptome mapping of a human cancer cell line. Mol. Syst. Biol. 2011, 7, 548. [CrossRef] [PubMed]

29. Kmiec, Z. Cooperation of liver cells in health and disease. Adv. Anat. Embryol. Cell. Biol. 2001, 161, 1-151.

30. Kelland, L. The resurgence of platinum-based cancer chemotherapy. Nat. Rev. Cancer 2007, 7, 573-584. [CrossRef] [PubMed]

31. Fausto, N.; Campbell, J.S. The role of hepatocytes and oval cells in liver regeneration and repopulation. Mech. Dev. 2003, 120, 117-130. [CrossRef]

32. Waga, S.; Stillman, B. The DNA replication fork in eukaryotic cells. Annu. Rev. Biochem. 1998, 67, 721-751. [CrossRef] [PubMed]

33. Bochman, M.L.; Schwacha, A. The mcm complex: Unwinding the mechanism of a replicative helicase. Microbiol. Mol. Biol. Rev. 2009, 73, 652-683. [CrossRef] [PubMed]

34. Freeman, A.; Hamid, S.; Morris, L.; Vowler, S.; Rushbrook, S.; Wight, D.G.; Coleman, N.; Alexander, G.J. Improved detection of hepatocyte proliferation using antibody to the pre-replication complex: An association with hepatic fibrosis and viral replication in chronic hepatitis c virus infection. J. Viral Hepat. 2003, 10, 345-350. [CrossRef] [PubMed]

35. Wisniewski, J.R.; Gaugaz, F.Z. Fast and sensitive total protein and peptide assays for proteomic analysis. Anal. Chem. 2015, 87, 4110-4116. [CrossRef] [PubMed]

36. Wisniewski, J.R.; Zougman, A.; Nagaraj, N.; Mann, M. Universal sample preparation method for proteome analysis. Nat. Methods 2009, 6, 359-362. [CrossRef] [PubMed]

37. Wisniewski, J.R.; Mann, M. Consecutive proteolytic digestion in an enzyme reactor increases depth of proteomic and phosphoproteomic analysis. Anal. Chem. 2012, 84, 2631-2637. [CrossRef] [PubMed]

38. Wisniewski, J.R.; Zougman, A.; Mann, M. Combination of fasp and stagetip-based fractionation allows in-depth analysis of the hippocampal membrane proteome. J. Proteome Res. 2009, 8, 5674-5678. [CrossRef] [PubMed]

39. Rappsilber, J.; Ishihama, Y.; Mann, M. Stop and go extraction tips for matrix-assisted laser desorption/ionization, nanoelectrospray, and LC/MS sample pretreatment in proteomics. Anal. Chem. 2003, 75, 663-670. [CrossRef] [PubMed]

40. Tusher, V.G.; Tibshirani, R.; Chu, G. Significance analysis of microarrays applied to the ionizing radiation response. Proc. Natl. Acad. Sci. USA 2001, 98, 5116-5121. [CrossRef] [PubMed]

41. Vizcaino, J.A.; Deutsch, E.W.; Wang, R.; Csordas, A.; Reisinger, F.; Rios, D.; Dianes, J.A.; Sun, Z.; Farrah, T.; Bandeira, N.; et al. Proteomexchange provides globally coordinated proteomics data submission and dissemination. Nat. Biotechnol. 2014, 32, 223-226. [CrossRef] [PubMed]

(C) 2016 by the authors; licensee MDPI, Basel, Switzerland. This article is an open access article distributed under the terms and conditions of the Creative Commons Attribution (CC-BY) license (http:/ / creativecommons.org/licenses/by/4.0/). 